\title{
MAKALAH \\ TENTANG PEMECAHAN MASALAH
}

Makalah untuk memenuhi mata kuliah pembelajaran matematika dasar Dosen pengampuh JUSMAWATI ,S.pd ,M.pd

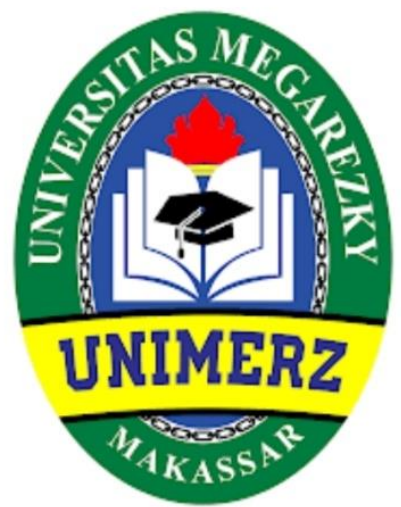

Disusun oleh :

Nama : Muh.hajrim

Nim : C1C120020

PRODI PENDIDIKAN GURU SEKOLAH DASAR

FAKULTAS KEGURUAN DAN ILMU PENDIDIKAN

UNIVERSITAS MEGA REZKY MAKASSAR 


\section{KATA PENGANTAR}

Puji syukur kita panjatkan kehadirat Allah SWT atas segala berkat, rahmat, serta hidayah-NYA yang tiada terkira besarnya, sehingga penulis dapat menyelesaikan makalah dengan judul pemecahan masalah". Dalam penyusunanya, penulis memperoleh banyak bantuan dari berbagai pihak, karena itu penulis mengucapkan terima kasih yang sebesar-besarnya kepada : Kedua orang tua dan segenap keluarga besar penulis yang telah memberikan dukungan, kasih sayang dan kepercayaan yang begitu besar. Dari sanalah semua kesuksesan ini berawal, semoga semua ini bisa memberikan sedikit kebahagiaan dan menuntun pada langkah yang lebih baik lagi. Meskipun penulis berharap isi dari makalah ini bebas dari kekurangan dan kesalahan, namun selalu ada yang kurang. Oleh karena itu, penulis mengharapkan kritik dan saran yang membangun agar makalah ini dapat lebih baik lagi. Akhir kata penulis berharap agar makalah ini bermanfaat bagi semua pembaca.

Gowa,16-juli-2021

Muh.hajrim 
KATA PENGANTAR

DAFTAR ISI

\section{BAB I PENDAHULUAN}

A.Latar Belakang

B.Rumusan Masalah

C.Tujuan

\section{BAB II PEMBAHASAN}

A.Pengertian Masalah Matematika

B.Pemecahan Masalah Matematika

C.Pentingnya Masalah Matematika

D.Contoh-Contoh Masalah Matematika berdasarkan Jenisnya

\section{BAB III PENUTUP}

A.Kesimpulan

B.saran

\section{DAFTAR PUSTAKA}




\section{PENDAHULUAN}

\section{A. Latar Belakang}

Pemecahan masalah diperlukan agar siswa dapat menyelesaikan problematika kehidupannya dalam arti yang luas maupun sempit. Kegiatan memecahkan masalah adalah bagian penting dalam belajar matematika. Dalam

kehidupan sehari-hari kita dihadapkan pada beraneka ragam masalah. Setiap masalah tentu saja memerlukan cara penyelesaian yang berbeda-beda. Salah satu di antaranya adalah melalui pemecahan masalah matematika (Mathematical Problem Solving). Memecahkan masalah merupakan suatu proses menerapkan pengetahuan yang telah diperoleh sebelumnya kedalam situasi baru yang belum dikenal. Siswa perlu mampu memecahkan masalah matematika, agar nantinya mereka mampu berpikir sistematis, logis dan kritis, serta gigih memecahkan masalah dalam kehidupan yang dihadapinya. Matematika sering dianggap menjadi pelajaran yang menakutkan bagi siswa, semakin tinggi jenjang pendidikan materinyapun semakin rumit. Untuk menghindari hal tersebut perlu diadakan pembelajaran yang menyenangkan sehingga proses pembelajaran matematika dapat menjadi kegiatan yang diminati oleh siswa.

\section{B.RUMUSAN MASALAH}

1. Bagaimana proses pemecahan masalah menggunakan langkah memahami masalah?

2. Bagaimana proses pemecahan masalah menggunakan langkah menyusun rencana?

3. Bagaimana proses pemecahan masalah menggunakan langkah melaksanakan rencana?

4. Bagaimana proses pemecahan masalah menggunakan langkah memeriksa kembali.

\section{C.TUJUAN}

1. Mendiskripsikan proses pemecahan masalah dengan menggunakan langkah 
memahami masalah.

2. Mendiskripsikan proses pemecahan masalah dengan menggunakan langkah menyusun rencana.

3. Mendiskripsikan proses pemecahan masalah dengan menggunakan langkah melaksanakan rencana.

4. Mendiskripsikan proses pemecahan masalah dengan menggunakan langkah memeriksa kembali.

5. Mendiskripsikan faktor-faktor apa saja yang dapat mempengaruhi pola belajar 


\section{A.Pengertian Masalah Dalam Matematika}

Menurut Fajar, masalah dalam Matematika adalah:1) segala sesuatu yang dikehendaki untuk dikerjakan,2) sebuah pertanyaan yang tidak dapat dijawab langsung.Sehingga masalah dalam matematika dapat juga ditaksirkan sebagai suatu pertanyaan yangmenghendaki suatu pemecahan.Sehubungan dengan itu Herman dan Akbar menegaskan bahwa: Suatu masalah tidak dapatdijawab langsung sebab masih harus menyeleksi informasi (data) yang diperoleh. Jawabanterhadap masalah tersebut tidak merupakan jawaban rutin dan mekanistik, namun merupakanstrategi dengan menggunakan pengetahuan dan pengalaman yang dimiliki. Dengan perkataanlain masalah yang dihadapkan kepada siswa haruslah sesuai dengan struktur kognitif siswa.Berdasarkan pendapat di atas, dapat ditarik suatu kesimpulan bahwa masalah dalammatematika adalah pertanyaan yang tidak dapat dijawab langsung karena pada titik awal belumdiketahui aturan atau hukum yang dapat digunakan untuk mendapatkan jawabannya dan siswamerasa tertantang untuk menyelesaikannya.

\section{B.Pemecahan Masalah Matematika}

Menurut Herman dan Akbar (1996/1997: 195), menyelesaikan masalahmerupakan prosesmenerima tantangan untuk menjawab masalah. Lebih fokus lagi, Bell(dalam Wanti, 2003: 14).menyatakan bahwa pemecahan masalah matematika ialah pemecahan situasi dalammatematika yang dianggap masalah oleh seseorang yang memecahkan masalah tersebut.Untuk menyelesaikan masalah matematika ada beberapa tahap yang harus dijalani. Pokjamengidentifikasi langkah-langkah pemecahan masalah menjadi empat langkah, yaitu: 1)langkah memahami masalah; 2) langkah menyusun rencana pemecahan masalah; 3) langkahmelaksanakan rencana yang telah disusun; 4) langkah meninjau ulang hasil pelaksanaan.Langkah-langkah pemecahan masalah model Pokja, menurut Sukirman (dalam Munawir,2008: 15) dapat dijelaskan sebagai berikut:

Langkah pertama, untuk dapat memahami masalah perlu memahami permasalahannya.Tanpa adanya pemahaman terhadap maslaah yang dihadapi, maka segala rencana dantindakan yang dilakukan tidak akan terarah bahkan dimungkinkan rencana dan tindakanyang dilaksanakan justru mempersulit permasalahan sehingga tidak dapat 
dipecahkan.Oleh karena itu, langkah pertama ini sangat besar artinya dalam pemecahan masalah.

Langkah kedua adalah menyusun rencana pemecahan masalah. Langkah ini dilakukandengan cara mencari hubungan antara hal-hal yang dikehendaki dengan hal-hal yangditanyakan. Masalah yang sudah pernah diselesaikan, konsep yang sudah pernah dimilikisebelumnya, sangat besar manfaatnya dalam menentukan hubungan yang terjadi antarayang diketahui dengan yang ditanyakan.

Langkah ketiga adalah melaksanakan rencana pemecahan masalah. Kalau pada waktumenyusun rencana yang berperan adalah pikiran, maka padalangkah pelaksanaan ini

Langkah keempat adalah meninjau ulang pelaksanaan rencana yang telah disusun. Padalangkah ini dilakukan pengkajian terhadap semua hal yang dilakukan. Validias setiaplangkah yang dilakukan untuk pemecahan masalah perlu dipertanyakan kembali agar dapatdiperoleh langkah yang lebih mudah terjamin kebenarannya. Tidak jarang terjadi suatulangkah tertentu yang menurut intuisi adalah sah, ternyata tidak pernah didukung oleh prinsip, konsep ataupun metode yang ada. Oleh karena itu, langkah ini tidak bolehdianggap remeh.Sedangkan menurut Kees (dalam Tjipto, 1991: 95) tahapan dari pemecahan masalahmeliputi tiga tahap:1.Langkah analisis terdiri dari:

a.Membaca soal dengan seksama untuk menganalisis informasi yang penting.

b.Menggambarkan diagram, skema atau gambar bila diperlukan.

2.Langkah penetapan model terdiri dari :

a.Mencari hubungan antara besaran-besaran yang diketahui dan yang ditanyakan.

b. Mengkombinasikan hubungan-hubungan itu dalam suatu model matematika.

c.Catat syarat-syarat bagi berlakunya model

3.Langkah penyelesaian terdiri dari :

a.Lakukan transformasi matematika.

b.Hitung sampai diperoleh jawaban. 
c.Periksa syarat-syarat berlakunya

d.Periksa ulang apakah setiap bagian sudah benar.Dari dua pendapat di atas, maka pembelajaran pemecahan masalah memiliki beberapalangkah yaitu:

1.Memahami masalah yakni mencari apa yang diketahui, ditanya, apa syaratsyaratnya,gambar dan grafik bila ada.

2.Membuat rencana penyelesaian yaitu rencana model matematika, membuat beberapa alternative pemecahan dan menyusun prosedur kerja untuk memecahkan masalah ataumencari hubungan yang diketahui, ditanyakan atau mengubahnya ke rumus

3.Penyelesaian masalah menggunakan rumus yang tidak disusun.

4.Pemeriksaan kembali jawaban yang ditemukan yakni memeriksa kembali jawaban danmengevaluasi jawaban.

C.Pentinganya pemecahan masalah matematika

Tantangan kehidupan yang semakin kompleks mendorong para ahli pendidikan untuk berpikir dan bekerja keras dalam upaya membantu generasi muda menjadi pemecah masalahhandal. Untuk mengembangkan kemampuan pemecahan masalah seseorang, latihan berpikirsecara matematis tidaklah cukup, melainkan perlu dibarengi pengembangan rasa percaya dirimelalui proses pemecahan masalah sehingga memiliki kesiapan memadai menghadapi berbagai tantangan dalam kehidupan nyata. Para ahli percaya bahwa kemampuan berpikir danketerampilan yang digunakan manusia dalam proses pemecahan masalah matematis

D.Contoh-Contoh Masalah Matematika berdasarkan Jenisnya

Masalah dalam matematika dapat dibagi atas beberapa macam. Para ahli membagi masalahtersebut dalam berbagai jenis berdasarkan sudut pandang masing-masing. Menurut Polya(1957) (dalam Dindyal, 2005: 70), masalah dibagi atas dua macam, yaitu masalah rutin danmasalah tidak rutin. Hal ini sejalan dengan pendapat Sternberg dan Ben-Zeev (1996: 32) bahwamasalah matematika terbagi atas masalah rutin dan masalah tidak rutin.Masalah rutin adalah suatu masalah yang semata-mata hanya merupakan latihan yangdapat dipecahkan dengan menggunakan beberapa perintah atau algoritma. Contoh: $(54-45)+(74-65)=\ldots .$. . Ini Adalah masalah rutin untuk semua siswa sekolah menengah karena apayang hendak 
dilakukan sudah jelas dan secara umum siswa tahu bagaimana menghitungnya.Masalah tidak rutin lebih menantang dan diperlukan kemampuan kreativitas dari pemecahmasalah. Menurut Sternberg dan Ben-Zeev (1996: 32), masalah yang tidak rutin muncul ketika pemecah masalah mempunyai suatu masalah tetapi tidak segera mengetahui bagaimanamemecahkannya.Jenis masalah dalam pembelajaran SD ada 4, yaitu:

1.Masalah Translasi

Masalah translasi adalah masalah yang berhubungan aktivitas sehari-hari siswa.

Contoh: Ade membeli permen 12 buah. Bagaimana cara Ade membagikan kepada 24orang temannya agar semua kebagian dengan adil?

2.Masalah Aplikasi

Masalah aplikasi adalah masalah yang menerapkan suatu konsep, rumus matematikadalam sebuah soal-soal matematika.

Contoh: Suatu kolam berbentuk persegi panjang yang berukuran panjang $\mathbf{2 0}$ meter danlebar 10 meter. Berapa luas kolam tersebut?

3.Masalah Proses/Pola

Masalah proses/pola adalah masalah yang memiliki pola, keteraturan dalam penyelesainnya. Contoh: 2, 4, 6, 8, ... . Berapa angka berikutnya?

4.Masalah Teka-teki

Masalah teka-teki adalah masalah yang sifat menerka atau dapat berupa permainan namuntetap mengacu pada konsep dalam matematika.

Contoh: Aku adalah anggota bilangan Asli, aku adalah bilangan perkasa, jikakelipatannku dijumlahkan angka-angkanya hasilnya adalah aku, siapakahaku?

Masalah di dalam matematika dapat diklasifikasi dalam dua jenis (Pusat Kurikulum, 2002a, b, dan c), yaitu :

1.Penemuan (Problem to find) 
yaitu mencari, menentukan, atau mendapatkan nilai atauobjek tertentu yang tidak diketahui dari soal serta memenuhi kondisi atau syarat yangsesuai dengan soal.

2.Pembuktian (Problem to prove),

yaitu prosedur untuk menentukan apakah suatu pernyataan benar atau tidak benar. Soal membuktikan terdiri atas bagian hipotesis dankesimpulan. Untuk membuktikan kita harus membuat atau memproses pernyataan yanglogis dari hipotesis menuju kesimpulan, sedangkan untuk membuktikan bahwa suatu pernyataan tidak benar kita harus memberikan contoh penyangkalnya sehingga pernyataantersebut menjadi tidak benar.Perhatikan beberapa contoh soal berikut:

a.Apa langkah pertama yang harus dilakukan dalam mengerjakan 3 1/2 : 5 1/4 ?

b.Tentukan hasilnya bila 1/4 x $6: 2$ 1/2 ?

c.Manakah yang lebih luas, kebun yang berbentuk persegipanjang dengan panjang 314m dan lebar $12 \mathrm{~m}$ atau kolam renang yang berbentuk lingkaran dengan jari-jarilingkaran 12 m?

d.Ani lebih tua dari Budi, Budi lebih tua daripada Chandra, Chandra lebih mudadaripada Deni. Siapakah yang paling muda di antara mereka?

e.Diketahui sejumlah bangun geometri datar, yaitu persegi, persegi panjang, segitiga,lingkaran, belah ketupat, jajar genjang, laying-layang, dan trapesium. Buatlahhubungan di antara mereka dalam bentuk diagram peta konsep!

f.Dengan cara bagaimana kita menunjukkan 6 dibagi 3 adalah 2?

g.Mengapa bilangan-bilangan ganjil dikalikan dengan bilangan genap selalumenghasilkan bilangan genap?

h.Mengapa setiap persegi adalah pesegi panjang?

i.Mengapa sebuah relasi belum tentu merupakan fungsi?

Dari soal-soal di atas soal a-e merupakan masalah penemuan, sedangkan soal fimerupakan masalah pembuktian, karena :

a.Pada soal poin a siswa akan menentukan langkah pertama untuk mendapatkan nilaidari $3 \frac{1}{2}: 5 \frac{1}{4}$ (masalah penemuan).

b.Pada soal poin b siswa akan mencari nilai dari 1/4 x $6: 2$ 1/2 (masalah penemuan). 
c.Pada soal poin c siswa akan menentukan mana yang lebih luas dengan mencari luaskebun dan kolam renang dengan ukuran masing-masing yang sudah ditentukan(masalah penemuan).

d.Pada soal poin d siswa akan menentukan kondisi yang sesuai soal dengan yangdiberikan (masalah penemuan).

e.Pada soal poin e siswa akan mencari, menentukan, dan mendapatkan hubungan bangun geometri datar yang diberikan dalam diagram peta konsep

(masalah penemuan).

f.Pada soal poin f siswa akan menunjukkan bahwa 6 dibagi 3 adalah 2 merupakan pernyataan yang bernilai benar

(masalah pembuktian).

g.Pada soal poin $\mathrm{g}$, $\mathrm{h}$ dan $\mathrm{i}$ merupakan masalah pembuktian diserahkan kepada Andasebagai latihan.

\section{BAB III \\ PENUTUP}

\section{A.Kesimpulan}

Masalah dalam matematika adalah pertanyaan yang tidak dapat dijawab langsung karena pada titik awal belum diketahui aturan atau hukum yang dapat digunakan untuk mendapatkan jawabannya dan siswa merasa tertantang untuk menyelesaikannya.Menurut Herman dan Akbar, menyelesaikan masalah merupakan proses menerimatantangan untuk menjawab masalah. Lebih fokus lagi, Bell menyatakan bahwa pemecahanmasalah matematika ialah pemecahan situasi dalam matematika yang dianggap masalah olehseseorang yang memecahkan masalah tersebut.Pemecahan masalah memiliki beberapa langkah, yaitu:1.Memahami masalah 2. Membuat rencana penyelesaian 3.Penyelesaian masalah 4.Pemeriksaan kembali jawaban yang ditemukanDalam dokumen National Research Council (1989), dinyatakan bahwa pengalamanpengalaman yang diperoleh melalui proses pemecahan masalah matematis memungkinkan berkembangnya kekuatan matematis yang antara lain meliputi kemampuan membaca danmenganalisis situasi secara kritis, mengidentifikasi kekurangan yang ada, 
mendeteksikemungkinan terjadinya bias, menguji dampak dari langkah yang akan dipilih, sertamengajukan alternatif solusi kreatif atas permasalahan yang dihadapi. Dengan demikian, pemecahan masalah matematis dapat membantu seseorang memahami informasi yang tersebardi sekitarnya secara lebih baik.Menurut Polya, masalah dibagi atas dua macam, yaitu masalah rutin dan masalah tidakrutin. Masalah di dalam matematika dapat diklasifikasi dalam dua jenis (Pusat Kurikulum,2002 a, b, dan c), yaitu: Penemuan

(Problem to find)

dan Pembuktian

(Problem to prove).

B.Saran

Semoga makalah yang telah kami buat dapat bermanfaat bagi pembaca dan khususnyakami sebagai penyusun. Dan diharapkan pembaca dapat menganalisis lebih jelas lagi mengenai pemecahan masalah Matematika dengan cara mencari literatur-literatu 


\section{DAFTAR PUSTAKA}

Jusmawati jusmawati, satriawati satriawati, Irman R, Abdul Rahman, Nurdin Arsyad, 2020. Model-model Pembelajaran Di Sekolah Dasar. Surabaya : Samudra Biru 